\title{
Judgements of SMEs' Legitimacy and Its Sources
}

\author{
Olga Ivanova Ruffo ${ }^{1} \cdot$ Kamel Mnisri $^{1} \cdot$ Christine Morin-Esteves ${ }^{1} \cdot$ Corinne Gendron $^{2}$
}

Received: 21 December 2017 / Accepted: 8 November 2018

(c) Springer Nature B.V. 2018

\begin{abstract}
Organizational legitimacy is an important resource, which provides access to other resources. As such, it impacts the survival chances of organizations. In this study, we examine the individual judgments of the owner-managers of small-and-medium size enterprises (SMEs) of the legitimacy of their own enterprise as well as their perception of the legitimacy evaluations of relevant stakeholders. This research is based on interviews with owner-managers of SMEs located in the Lorraine region of France. The results show that when legitimacy is perceived as acquired, their judgments are based on instrumental, relational and moral evaluations, whereas when legitimacy is perceived as being deferred, judgement is based on mainly instrumental evaluations and when they report not being in position to judge their own legitimacy, their judgements are based on moral evaluations. In addition, the legitimacy judgements employed are associated with the different types of legitimacy sought by the SME owner-managers. Moreover, they perceive the validity cues coming from clients and employees as the most important sources of legitimacy. Other stakeholders are accorded secondary importance in granting legitimacy.
\end{abstract}

Keywords Legitimacy-as-perception $\cdot$ SMEs $\cdot$ Owner-managers $\cdot$ Stakeholder theory

\section{Introduction}

Legitimacy affects organizational behavior and influences the survival chances and performance of organizations (Deephouse et al. 2016). We know that small and big companies do not face the same legitimacy dynamics (Ivanova and Castellano 2012). Small companies are not simply 'little big firms' (Fitjar 2011; Tilley 2000). Even though all organizations are resource-constrained and their legitimacy can be debated, SMEs have higher chances of failure. This is mainly due to their liability of smallness and higher institutional pressures coming from their embeddedness in local

Olga Ivanova Ruffo

olga.ivanova-ruffo@icn-artem.com

Kamel Mnisri

kamel.mnisri@icn-artem.com

Christine Morin-Esteves

christine.morin-esteves@icn-artem.com

Corinne Gendron

gendron.corinne@uqam.ca

1 ICN Business School, CEREFIGE, 86 rue du Sergent Blandan, CS 70148, 54003 Nancy Cedex, France

2 Université du Québec à Montréal, CEREFIGE, C.P. 8888, succ. Centre-ville, Montréal, QC H3C 3P8, Canada networks of actors (Freeman et al. 1983). Hence, small companies have to work to improve their legitimacy (Russo and Perrini 2010) in order to be able to constantly re-negotiate the access to resources from their environment (Pfeffer and Salancik 2003/1978).

In this study, we look at the perception held by SME owner-managers and examine how they understand the legitimacy of their own enterprise and its sources. Our singular contribution is to show how they judge the legitimacy of their companies as well as the way they perceive the legitimacy granted by relevant stakeholders. Owner-managers are definitive stakeholders of the SME (Sen and Cowley 2013) and their psychological characteristics determine to a great extent the behavior of their enterprises (Jenkins 2006). On a personal level, legitimacy is viewed as an internal value linked to the feelings of obligation and responsibility to others and as such, it represents an internal motivational guide to behavior (Tyler 2006). In comparison to large companies, SMEs are characterized by a high level of personalization and in certain way, the owner-manager makes the company (Paradas 2007). As a result, their individual legitimacy judgements may influence profoundly the behavior of their own enterprises (Johnson et al. 2006).

While the existing research has extensively studied the legitimacy challenges of young and small ventures or the 
so-called entrepreneurial legitimacy (Delmar and Shane 2004; Chan 2012), in this particular study, we focus on established SMEs. Previous research has highlighted the need to examine how individuals come to judge existing institutional arrangements and entities as legitimate or illegitimate (Tost 2011). Individual judgements and perceptions constitute the micro-motor of legitimacy, which is the basis on which legitimacy as a collective phenomenon is built (Tost 2011). Nevertheless, to the best of the researchers' knowledge, the question of how SME ownermanagers perceive the legitimacy of their enterprises has not been studied yet. We focus attention on the legitimacy of SMEs given their heightened importance in recent years; today, they are perceived as the growth engines of national economies in many parts of the world (Jamali et al. 2009). Hence, governments recognize their important role in driving the GDP growth and national employment levels. As a result, understanding what determines their behavior is an important issue not only for academic researchers, but also for practitioners and public policy makers. Therefore in this research, we ask the following questions: (1) how do owner-managers of SMEs evaluate their enterprise's legitimacy? and (2) how do they understand the basis on which relevant stakeholders grant legitimacy to their own enterprise? The answer to these questions will help us understand the bases for legitimacy as a condition for SMEs' survival and prosperity, which can consequently shed some light on their behavior.

The paper is organized as follows: first, we look at the literature on legitimacy-as-perception. Next, we study SME-specific context in regard to legitimacy. We then turn to examining the individual legitimacy judgments of SME owner-managers and their evaluations of the validity cues coming from relevant stakeholders. The paper goes on to present the empirical setting, research design and data analysis. We conclude by discussing the results and by examining contributions to the literature and avenues for future research.

\section{Organizational Legitimacy: Definition and Typologies}

Deephouse et al. (2016, p. 10) define organizational legitimacy as "the perceived appropriateness of an organization to a social system in terms of rules, values, norms, and definitions." Legitimate organizations usually develop offices and procedures which demand the obedience and loyalty of their members and the support and endorsement of non-members (Brummer 1991). Organizations develop networks of relationships involving reciprocal duties among and between members and non-members and to the extent to which these duties are respected, the organization is perceived as legitimate (Brummer 1991). In effect, legitimacy is a belief in the rightness of an organization and its procedures and objectives, and it depends on the ongoing acts of belief by countless individuals (Berger 1981). In its essence, legitimacy has a moral character since the legitimate organization is perceived to deserve consideration and support (Brummer 1991). Legitimacy can then be seen as a resource (Dowling and Pfeffer 1975) and as such, it has important consequences for organizations (Deephouse et al. 2016). It may enhance the survival chances of an entity (Meyer and Rowan 1977), its ability to compete for other resources (Deephouse et al. 2016) and can also impact its financial performance (Deephouse 1996).

Legitimacy can be theorized as a thing (legitimacy-asproperty), as a process (legitimacy-as-process) and as a form of socio-cognitive perception or evaluation (legitimacy-asperception) (Suddaby et al. 2017). In this study, we focus on legitimacy as a perception held by an individual (Tost 2011); in our case, the owner-manager of the SME, who steps into the role of an evaluator of the legitimacy of his/her own enterprise as well as his/her understanding of the perceptions held by relevant stakeholders. Due to the high level of personalization associated with SMEs (Paradas 2007), the owner-manager is the only definitive stakeholder and his/ her perception of the legitimacy of the enterprise has direct consequences on the latter's behavior.

In the legitimacy-as-perception perspective, legitimacy emerges in the interplay between individual (micro-) and collective (macro-) cognition (Bitektine and Haack 2015). It is the individuals who perceive an entity, judge its legitimacy and act upon their judgments (Hoefer and Green 2016). Hence, at the individual level, legitimacy is acknowledged as a propriety judgment (Tost 2011) or the evaluator's assessment of the appropriateness and acceptability of an object (any entity, such as an individual, organization, nation-state, practice, etc.) (Suddaby et al. 2017; Zelditch 2001). At the collective level, legitimacy is present in the form of validity, i.e., an opinion shared by the majority of the actors (Berger 1981; Tost 2011). Validity has an important effect on the propriety judgements of individuals since the latter tend to adopt judgements they consider valid (Suddaby et al. 2017). Even though validity exists independently of the opinion of a single evaluator, individuals form validity perceptions or beliefs (Bitektine and Haack 2015). The latter refer to a given evaluator's perception that an entity is deemed appropriate by others in a collectivity of evaluators, independent of the focal evaluator's private endorsement of that entity (Johnson et al. 2006). In cases when evaluators privately do not perceive an entity as legitimate but believe that others in the collectivity perceive it as appropriate, they may conform to the judgements of others (Bitektine and Haack 2015). For example, some individuals may not perceive a particular 
Table 1 Legitimacy typology

\begin{tabular}{llll}
\hline Type of legitimacy & Sub-type of legitimacy & Basis of legitimacy & References \\
\hline $\begin{array}{l}\text { Regulatory legitimacy } \\
\text { Normative legitimacy }\end{array}$ & Regulatory standards, rules and laws & Scott (2001, 2003) \\
& Technical legitimacy & $\begin{array}{l}\text { Core technology, key competencies, quality of services } \\
\text { and qualifications of actors }\end{array}$ & Ruef and Scott (1998) \\
Multural-cognitive legitimacy & & $\begin{array}{l}\text { Management efficiency } \\
\text { Ruef and Scott (1998) }\end{array}$ & Scott (2001, 2003) \\
\hline
\end{tabular}

practice as appropriate, but if they perceive that others view it as such and act accordingly, they will permit that it governs their own behavior and accept the practice as legitimate (Tost 2011; Zelditch 2001). Hence, the legitimacy-as-perception perspective supports a multi-level approach, but draws attention primarily to the individual, or the micro level. The macro level holds the antecedents (validity) and bears the consequences of individual legitimacy judgements (Suddaby et al. 2017).

In order to understand better the sources of the individual legitimacy judgments of the SMEs' owner-managers, we present below the legitimacy typologies commonly used in the management literature. Even though numerous legitimacy typologies have been developed (Scott 2001; Zimmerman and Zeitz 2002; Higgins and Gulati 2006; for the full list, please refer to Table 2 in Bitektine 2011), it is important to note that each typology reflects different dimensions of the legitimacy concept.

The most widely accepted legitimacy typology is the one provided by the neo-institutionalists (see Table 1). It is based on the three pillars of institutions-regulatory, normative and cognitive (Scott 2001). Regulatory legitimacy is the perception that an entity, practice or an individual conforms to the regulatory standards, rules and laws. Normative legitimacy exists when the goals of an entity are congruent with the broadly accepted values and norms. Cultural-cognitive legitimacy is embedded in the socio-cultural environment and provides frameworks on which normative and regulative systems are constructed (Scott 2003). An entity is said to have cultural-cognitive legitimacy when it achieves a takenfor-granted status (Scott 2001).

In addition, Ruef and Scott (1998) examined closer normative legitimacy and distinguished between two main types: technical and managerial legitimacy (see Table 1). Technical legitimacy focuses on organizational features, such as core technology, key competencies, quality of services, and qualifications of actors. Managerial legitimacy emphasizes features related to efficiency in management. Usually, research shows that these two types of legitimacy are aligned, but sometimes organizations can be high on one and low on the other. For example, Ruef and Scott (1998) showed that organizations can be low on managerial and high on technical legitimacy.
Therefore, based on the above-mentioned legitimacy typology, for the purpose of our study, we adopted three types of legitimacy: regulatory, normative and cultural-cognitive legitimacy (see Table 1). Within normative legitimacy, we distinguish between technical and managerial legitimacy as per Ruef and Scott (1998).

The legitimacy dynamic is different for small and large firms (Ivanova and Castellano 2012). In the section below, we look at aspects specific to the SMEs' context, which determine their legitimacy dynamics.

\section{Organizational Legitimacy and SMEs}

Small organizations are the most common type of enterprise (Soriano and Dobon 2009). For the purpose of this article, we adopt the standard European Union definition of SMEs: organizations with fewer than 250 employees, a turnover of $<€ 50$ million euros and a balance sheet total of $<€ 43$ million. This definition includes micro- (from 1 to 9 employees), small- (from 10 to 49 employees) and medium- (from 50 to 249 employees) enterprises (McIntyre 2003, p. 10).

According to the European Commission, SMEs represent 99\% of all businesses in the European Union. In the past 5 years, small enterprises have created more than $85 \%$ of the new jobs and provided around $2 / 3$ of the total private sector employment in the EU. This is why they are considered as

Table 2 SMEs stakeholders' salience classification (Sen and Cowly 2013)

\begin{tabular}{lll}
\hline Stakeholders & Attributes possessed & Salience classification \\
\hline Owner-managers & $\begin{array}{c}\text { Power/legitimacy/ } \\
\text { urgency }\end{array}$ & Definitive \\
Employees & Power/legitimacy & Dominant \\
Customers & & \\
Suppliers & & \\
Investors & & Discretionary \\
Family of owners & Legitimacy & \\
Political groups & & \\
Trade associations & & \\
Community & & \\
\hline
\end{tabular}


critical backbones of economic health and vitality not only in the developed but also in the emerging economies (Jamali et al. 2009).

Small companies are not simply 'little big firms' and should not be studied as such (Fitjar 2011; Tilley 2000). A common assumption is that SMEs are homogenous, their defining characteristic being their size (Jenkins 2006). But in legal terms, SMEs can take different forms from sole proprietorships and partnerships to cooperatives and other arrangements (Fitjar 2011). One common attribute though is that the psychological characteristics of the owner-manager determine to a larger extent the behavior of SMEs (Jenkins 2006). Since on an individual level, legitimacy is viewed as an internal value linked to the personal feelings of obligation and responsibility to others, along with the other moral values, it represents an internal motivational guide to the SME owner-manager's behavior (Tyler 2006). As a result, the individual legitimacy judgments of the owner-manager are expected to influence his/her own behavior towards the SME and the external stakeholders. Eventually, this will have consequences for the behavior of the enterprise itself due to the high level of personalization of the SMEs (Paradas 2007).

The importance of the micro-macro interplay in the formation of individual legitimacy judgments calls our attention to the context of SMEs, which determines the latter's legitimacy needs. In the section below, we describe the particularities of the SME context in general followed by the specificities of the French context and the region of Lorraine.

\section{The Context of SMEs}

SMEs face different institutional pressures (Peng 2003). They are deeply embedded in their local communities (Russo and Perrini 2010; Fitjar 2011). SME managers have close personal contact with their employees, which sometimes blurs the relationship between them. In addition, the fact that SMEs have often informal procedures for recruitment leads to hiring of acquaintances, family members and friends (Fitjar 2011). Thus, employees often show higher involvement and are more flexible in their day-to-day activities. Moreover, close personal relationships are not only restricted to employees. Managers of small businesses can also be in close contact with suppliers, customers and sometimes competitors. They tend to live in the same or close neighborhoods and maintaining a good reputation and strong personal relationships is important. In addition, they are less mobile, are expected to respect local norms of collective behavior and their businesses are perceived to be pillars of the community. They are more dependent than large firms on strong community relationships in order to survive (Russo and Tencati 2009). Hence, small companies face stronger institutional pressure from the local community to respect the norms of collective behavior. In addition, the local embeddedness of SMEs and the lower number of stakeholders they deal with increases the relative power of the latter (such as family, friends and local community).

In addition, SMEs are subject to the liability of smallness. In general, they have higher chances of failure (Freeman et al. 1983) due to the fact that they have fewer resources (i.e. financial, managerial, human and informational), less well-trained managers, and less developed relationships with creditors (Bruderl and Schussler 1990) and other external stakeholders (Singh et al. 1986). Small organizations are more vulnerable since they can more easily import instability from the environment (Smallbone et al. 1999). They are preoccupied by immediate issues of day-to-day survival; their managers take on many tasks themselves and lack the time to strategize about the future (Fitjer 2011).

According to the Center of Documentation of the Economy and Finance (CEDEF-Centre de Documentation Economie-Finance), in 2014 there were approximately 4 million SMEs in France, accounting for $99.9 \%$ of all French enterprises. They provided $48.5 \%$ of all employment and $43.4 \%$ of the value added. The region of Lorraine (where we collected data in 2013) is located in the North-Eastern France. The region's development has traditionally depended on the mining sector but the role of the latter declined significantly in the 1980s. In addition, due to the continuing deindustrialization after 2000, Lorraine faces one of the highest unemployment levels in metropolitan France (Conseil Economique Social et Environnemental de Lorraine 2013).

The specific context in which SMEs operate influences the individual legitimacy judgments of SME managers. We discuss this in the section below.

\section{Individual Legitimacy Judgements of SME's Owner-Managers}

As it was mentioned previously, two dimensions explain the formation of legitimacy judgments on an individual level-propriety and validity. Even though the individuallevel judgments of legitimacy (propriety) can differ from the collective-level validity of an entity, the validity cues that come from the social context shape the individual perceptions (Suddaby et al. 2017) since the individual evaluators observe other actors and receive messages from them conveying their individual judgments (Bitektine and Haack 2015). In this way, they form validity beliefs_-judgements "about what the validated 'consensus' is" (Bitektine and Haack 2015, p. 51).

In addition, previous research looks at the process of judgment formation and judgement use as two distinct processes. In the process of judgement formation, individuals perform either evaluative (effortful) or passive processing of information, which leads to the formation of a legitimacy 
judgement that represents the entity under scrutiny as either appropriate or not to its social context (Tost 2011, p. 695). Judgement formation is based on the validity cues, which come from the environment as well as instrumental, relational and moral evaluations of the individual. With instrumental evaluation, an entity will be judged as legitimate when it is perceived to promote the material interest of the individual. With relational evaluation, legitimacy emerges from the extent to which a social entity communicates that the individual evaluator is accorded respect, dignity and status within the group context and through group membership. The moral evaluation is based on the set of values guiding the morality of the evaluator (Tost 2011). On the other side, the validity cues are based on the evaluations that an entity is legitimate or not as granted by different stakeholders.

The legitimacy judgment of the owner-managers is fundamental in determining the behavior of their enterprise. The small business is normally the primary source of income for the owner-manager and by definition it consumes the majority of his/her time and resources (Fassin et al. 2011). Therefore, the SME is characterized with a strong personalization, which sometimes can even put the existence of the company in danger (Paradas 2007). The boundary between the private and the professional life of the owner-managers is often difficult to set, and hence the individual in a certain way makes the company (Paradas 2007). The individual perception of the SME's legitimacy is an internal value for the small business owners linked to their personal feelings of obligation and responsibility (Tyler 2006). In this way, it is similar to but also different from moral values. While legitimacy is the perceived obligation to social arrangements and entities (in this case being the small business ownermanagers' enterprise), moral values are personal standards with which people try to align their behavior (Tyler 2006). In most cases, legitimacy and moral values go hand in hand, but it can happen that they diverge (Tyler 2006).

In any case, it is worthwhile to examine whether by employing instrumental, relational and moral evaluations, the SME's owner-managers search for different type of legitimacy (regulatory, normative technical and/or normative managerial, and cultural-cognitive). We also have to consider that in this process of individual legitimacy judgmentformation, the validity cues coming from the context are important (Tost 2011). Therefore, below we look at the different groups of stakeholders who, by granting or not legitimacy, provide cues, which influence the owner-managers in the formation of their legitimacy judgements.

\section{Stakeholders as Evaluators of SMEs' Legitimacy}

Different internal and external stakeholders and/or institutions can be perceived as sources of validity cues of organizational legitimacy (Ruef and Scott 1998). As mentioned above, SMEs are embedded in local stakeholder communities comprised of customers, employees, suppliers and other local entities (Fuller and Tian 2006). The nature of doing business is very personal, often with direct contact between the owner and the customers. Hence, their legitimacy with immediate stakeholders is at stake in a far more direct and personal way than it is with large corporations (Fuller and Tian 2006).

The stakeholder theory (Freeman 1984) looks at the importance of stakeholders, defined as "any group of individuals, who can affect or is affected by the achievement of the firm's objectives" (p. 47). Mitchell et al. (1997) proposed a stakeholder salience model, which ranks the stakeholders in terms of three attributes: power, legitimacy and urgency. Stakeholders possessing more attributes are deemed more salient (Sonpar et al. 2010). Depending on the type of attribute (power, legitimacy and/or urgency), they are identified as definitive, dominant and discretionary (Sen and Cowley 2013). Stakeholder salience is dynamic and the actions of the stakeholders, and/or any shift in the environment, can cause it to change (Sonpar et al. 2010).

Based on Mitchell et al. (1997)'s model, Sen and Cowley (2013) have developed the following salience classification for SMEs' stakeholders (see Table 2).

\section{Definitive Stakeholders}

SMEs have only one definitive stakeholder and this is the owner-manager. We elaborate on how they form judgments about their own enterprises below, in the section "Legitimacy, Enterprise and the Owner-Manager".

\section{Dominant Stakeholders}

The dominant stakeholder group is comprised of customers, employees, suppliers and investors. For the survival of the company, it is very important that it produces quality products and services that customers want (Sen and Cowley 2013). Since often SMEs rely heavily on fewer customers, they are under constant scrutiny by them. Hence, customers are the most important external stakeholder group for SMEs (Westrenius and Barnes 2013). Employees, with whom owner-managers often have personal relationships (Fitjar 2011), constitute another important source of legitimacy. Their motivation to work and the ability to retain them is of primary importance to the small company. The level of salience of suppliers is determined by the SME's level of dependence on the supplier and the availability of alternatives (Westrenius and Barnes 2013). As for investors (banks), since access to resources, including financing, is one of the most important disadvantages of small businesses, maintaining a good relationship with them, which can assure 
timely investments, is of pivotal importance to any small enterprise and an undeniable signal of legitimacy.

\section{Discretionary Stakeholders}

According to Sen and Cowley (2013), the discretionary stakeholders include family members, political groups (associations), standard-setting and award-granting organizations and community. The degree of importance of the family may vary from one owner-manager to another (Westrenius and Barnes 2013) but as a rule most owner-managers are in search of balance between their professional and personal activities. In terms of associations (political groups), SMEs take part in them since they provide a platform to voice their opinion against more powerful stakeholders (Lepoutre and Heene 2006) and influence political decision-making (Sen and Cowley 2013). The literature on SMEs also emphasizes the importance of certificates, prizes, awards, and participation in trade show exhibitions-especially for small companies that operate in international or global markets (Mort et al. 2012). For example, ISO certification increases small business' opportunities to cooperate with suppliers, clients, competitors and also enter new markets (Boiral 2003). Finally, SMEs are strongly embedded in local communities. Hence, community is regarded as an important stakeholder, needed for receiving the social license to operate (Russo and Perrini 2010). This can explain SMEs engagement in actions that meet local community's expectations and requirements.

Based on the above literature review, we examine two main research questions: (1) how do owner-managers of SMEs evaluate the legitimacy of their enterprises? and (2) how do they understand the basis on which relevant stakeholders grant legitimacy to their enterprise? In the section below, we present the research design that we employed to answer these research questions.

\section{Research Design}

For our investigation into the legitimacy judgments of SME managers, we employed a qualitative methodology. Data was collected from the region of Lorraine in North-Eastern France through semi-structured face-to-face interviews. This technique enriches the depth of the information provided (Cooper and Schindler 2001) due to its flexibility. The research was part of a larger study on values, leadership and legitimacy for which the authors have elaborated a single comprehensive interview guide.

We chose a qualitative research design because we wanted to achieve an in-depth understanding of the use of individual legitimacy judgments and their sources. Qualitative methods are appropriate to study legitimacy since the concept is a second-order construct (Deephouse and Carter
2005; Delmar and Shane 2004). To test the research question, we used iterations between collected data and theoretical knowledge.

We collected data from a total of 24 SME owner-managers, of whom two-thirds were men and one-third were women. Twenty-three of the interviewees were the actual owners of their respective enterprises and one had a managerial position. All managers originally came from the region of Lorraine and their average age was 45 years old. The industry sectors represented in the sample included: human resources (1), accounting (1), communication (5), construction (3), industry (6), real estate (3), consulting (4), and personal services (2).

The interviews were recorded, transcribed and coded with Atlas.ti. Before we started the coding, one interview was used as a learning tool- the three researchers coded that interview together in order to standardize the coding process. In this preliminary stage, they coded each paragraph (comprised of 9-20 lines) separately and then they discussed the coding in terms of similarities and differences in the coding procedure. The process continued until we reached a level of agreement of around $90 \%$ regarding the retained codes which corresponds to acceptable levels of reliability (Krippendorff 2004; Neuendorf 2017). This interview was not included in the final data set. The codes were generated abductively, which means that we went back and forth between the theory and the first interview in order to stabilize the codes.

After this preliminary stage, the researchers coded the 24 interviews, which comprised the study sample. In the first stage of the coding, each researcher got a set of 8 (out of 24) interviews and coded them independently. In the second stage, the interviews were exchanged and the coding was verified by a second researcher. Hence, each researcher got a new set of 8 interviews (not coded by him/her) and confirmed the coding on a printed document. For each document, some mistakes were corrected and some adjustments of the coding were made, including filling gaps where codes were missed. At the final stage, each researcher got another set of 8 interviews to verify the codes and enter in Atlas.ti the corrections made in the second stage. This way, each researcher coded or verified the coding of all 24 interviews.

Afterwards, we proceeded with data analysis of the cooccurring codes. Since our context unit was the paragraph (comprised of 9-22 lines), we considered two codes as cooccurring when they appeared in the same paragraph. For each relevant concept associated with legitimacy with the help of Atlas.ti, we generated query reports. Each query report contains all the paragraphs across all interviews where the two codes appear or co-occur together. We then read and analyzed the paragraphs in order to determine the type of relationship between the two codes. The results are presented in the following section. 
Table 3 The most frequent codes

\begin{tabular}{ll}
\hline Codes & Total frequency \\
\hline Enterprise & 563 \\
Clients & 267 \\
Collaborators & 227 \\
Owner-managers & 219 \\
Values & 152 \\
Responsibility & 131 \\
Creativity & 130 \\
Team & 95 \\
Family & 92 \\
Legitimacy & 40 \\
\hline
\end{tabular}

Table 4 Co-occurrence of most frequent codes with code 'legitimacy'

\begin{tabular}{lcc}
\hline Codes & Total frequency & $\begin{array}{l}\text { Co-occurrence with } \\
\text { code 'legitimacy' }\end{array}$ \\
\hline Enterprise & 563 & 25 \\
Values & 152 & 12 \\
Client & 274 & 12 \\
Owner-manager & 78 & 10 \\
Image & 50 & 6 \\
Responsibility & 87 & 6 \\
Recognition & 29 & 6 \\
Collaborators & 105 & 6 \\
\hline
\end{tabular}

\section{Data Analysis}

In this article, the authors look at how owner-managers judge the legitimacy of their own enterprise as well as their perception of the legitimacy granted by different stakeholders. As a definitive stakeholder (Sen and Cowley 2013), an owner-manager holds a perception about whether his/her enterprise is legitimate (propriety) and about what other stakeholders think about the legitimacy of their enterprise (validity beliefs). To analyze the data collected from 24 SMEs, we proceeded in the following way. To start with, we present the most frequent codes in the discourse of the owner-managers across all interviews (see Table 3). This indicates how the code 'legitimacy' is positioned in comparison to the other codes.

Afterwards, based on the data analysis, 9 codes were identified as the most frequently associated codes with the code 'legitimacy' (see Table 4). ${ }^{1}$ This means that they

\footnotetext{
${ }^{1}$ Codes, such as 'creativity' and 'France' were also frequently associated with the code legitimacy. Nevertheless, they were not considered by the researchers, because the analysis of the query reports showed that they do not relate to the code 'legitimacy' in a relevant way.
}

Table 5 Pertinent non-frequent co-occurring codes with code 'legitimacy'

\begin{tabular}{lll}
\hline Codes & $\begin{array}{l}\text { Total fre- } \\
\text { quency }\end{array}$ & $\begin{array}{l}\text { Co-occurrence with } \\
\text { the code 'legitimacy' }\end{array}$ \\
\hline $\begin{array}{l}\text { Family } \\
\begin{array}{l}\text { Investors (shareholders-18 } \\
\text { and bank-26) }\end{array}\end{array}$ & 92 & 3 \\
Certification & 31 & 3 \\
Norms & 17 & 3 \\
Regulation & 27 & 2 \\
Suppliers & 39 & 2 \\
Community & 13 & 2 \\
\hline
\end{tabular}

co-occur in the same paragraph with the code 'legitimacy'. In order to better understand their relationship with the code 'legitimacy', we also added other pertinent but non-frequent codes to the analysis (see Table 5). They were identified as pertinent based on the literature on SMEs-the codes 'family', 'investors', 'suppliers' and 'community' are stated as being dominant or discretionary stakeholders (Sen and Cowley 2013). The codes 'regulations', 'norms' and 'certification' were identified as pertinent based on the neo-institutional legitimacy typology (presented in Table 1).

Based on the data analysis of the co-occurring codes with the code 'legitimacy', the owner-managers express their individual judgments about the legitimacy of their enterprise. The code 'legitimacy' is mainly associated with the codes 'clients' and 'collaborators,' which reveals the relationship with these stakeholders as the main source of legitimacy. Moreover, the code 'legitimacy' is associated with the codes 'values' and 'responsibility' as well as 'image' and 'recognition', which reflects the challenges that SMEs face in achieving congruence between their internal values and their externally-projected image. Indeed, we acknowledge that the owner-managers judge the legitimacy of their enterprise in terms of their stakeholders (mainly, clients and collaborators), and this legitimacy brings into focus two sets of influences; namely, values and responsibilities on one side and image and recognition, on the other.

The analysis starts by investigating the way owner-managers perceive the legitimacy of their enterprise. We then analyze the way they understand the basis on which relevant stakeholders grant legitimacy before examining the challenges faced by SMEs when they try to acquire and convey their legitimacy.

\section{Legitimacy, Enterprise and the Owner-Manager}

In order to understand how owner-managers perceive the legitimacy of their own enterprise, we studied the relationship between the frequent codes 'enterprise' and 
Table 6 Co-occurrence of codes enterprise and owner-manager with the code 'legitimacy'

\begin{tabular}{lll}
\hline Codes & Frequency & $\begin{array}{l}\text { Co-occurrence } \\
\text { with code 'legiti- } \\
\text { macy' }\end{array}$ \\
\hline Enterprise & 563 & 25 \\
Owner-manager & 85 & 10 \\
\hline
\end{tabular}

'owner-manager' by examining the co-occurrence of each of these codes with the code 'legitimacy' (see Table 6).

\section{Enterprise and Legitimacy}

When analyzing the relationship legitimacy-enterprise, we find that the owner-managers associate legitimacy with the right of the enterprise to exist. A very big role in determining the relationship between 'legitimacy' and 'enterprise' is the sector or industry. In some sectors (i.e., services to senior citizens) where the government and non-government entities co-exist, the legitimacy of for-profit entities might be questioned. In these sectors, companies might be susceptible to a changing institutional environment due to political decisions. In order to understand better the enterprise-legitimacy relationship, we analyze the most frequent codes that are associated with these two codes. The analysis shows that these are the following:

Codes legitimacy - enterprise - client $=$ Frequency: 9

Codes legitimacy - enterprise - values $=$ Frequency: 6

The enterprise-legitimacy relationship is moderated by the code 'clients.' The association with the code 'clients' shows that providing good service, going the extra step and engaging with the client is of central importance for the legitimacy of the enterprise. For example, one interviewee whose enterprise is in the communication sector stated: "Well, legitimacy in the sense that we provide a real service to our clients and we are engaged with our clients, we are the last actor in the supply chain and we are often there to save the situation." Having satisfied clients is an expression of possessing the technical competencies (translated into high quality services and experiences for the clients) in the main sector of activity. For example, to the question of the interviewer: "So, how do you define this notion of legitimacy?", "That we have competencies, it's a notion of competencies and humility, to know how to question yourself every day in order to learn and this way, to educate yourself every day and educate your employees. As long as we are sure we have competencies, we have legitimacy to sell, to exchange our ideas, to advance," said one respondent whose enterprise is in the communication sector.
The other code which moderates the legitimacy-enterprise relationship is 'values.' The personal moral values of the owner-manager influence whether (s)he will grant the enterprise legitimacy (Morin-Estèves et al. 2017/2018). Some of them perceive their enterprises as legitimate, others do not and still a third group states that they are not in a position to judge the legitimacy of their own enterprise. These three situations are illustrated with examples in the sub-section to follow.

\section{Owner-Manager and Legitimacy}

The majority of the owner-managers perceive their enterprise as legitimate based on the fact that they have clientsfor example when asked by an interviewer "Are you considered as legitimate in what you do?", one respondent whose enterprise is in the communication sector said: "I think so. Because if not, we wouldn't have had clients." The experience of the clients and their satisfaction is the basis for evaluating their enterprise legitimate. As one interviewee with main domain of activity in the information services pointed out: "We deliver a good experience to our clients. So, yes, I think we are legitimate in what we do." Another way of looking at it is that the enterprise is legitimate because it has the competencies required in a particular industry, which gets reflected in having satisfied clients. In addition, depending on the sector, legitimacy comes from the expertise (and certification) of their employees. For example, an interviewee from the consulting sector stated: “... when people have to do business with certified public accountant, auditors, very quickly for them this is a guarantee of quality." In certain cases, owner-managers perceive their enterprise to be legitimate when they have overcome financial difficulties and have realized positive financial results. An interviewee from the heavy industry said: "Last year we did $-270,000$ euros. The worst financial statement that we have ever had. It was due to the fact that we served all debts. Now, I have a cash flow worth 800,000 euros. I worked hard, we all worked hard to have this result... Because we talk about legitimacy, this is how we become legitimate, we fight."

Some owner-managers express doubts about the legitimacy of their enterprise because they associate it with their personal legitimacy. For example, one respondent whose enterprise is in heavy industry stated: "I'd like to say that when I achieve my objectives, meaning to develop this enterprise, to transfer it, to secure my family, I'd consider myself legitimate." In fact, the role of the enterprise (and the personal role of the owner-manager) is to provide the family with financial security. Yet, a third group of owner-managers state that they are not in a position to judge the legitimacy of their own enterprise. It sounds pretentious and lacking the value of humility which they project and seek to transfer to their employees. For example, one respondent from the 
Table 7 Co-occurrence of codes 'clients' and 'collaborators' with code 'legitimacy'

\begin{tabular}{lll}
\hline Codes & Frequency & $\begin{array}{l}\text { Co-occurrence } \\
\text { with code 'legiti- } \\
\text { macy' }\end{array}$ \\
\hline Clients & 274 & 12 \\
Collaborators & 105 & 6 \\
\hline
\end{tabular}

communication sector stated: "It would be too pretentious to say it, I don't know... we have...yes, several times I received feedback from people who give me this image but I'm not at ease with it. I prefer to be in my corner, doing my work." These owner-managers state that it is the role of external stakeholders to evaluate them as legitimate or not; in this way, they do not judge the legitimacy of their enterprise themselves, which feels inappropriate. When asked to evaluate whether his/her own enterprise is legitimate, one ownermanager from the heavy industry stated: "I don't want to... it's against our nature. In our enterprise, we always developed this humility."

After examining the complex relationship between SME, owner-manager and their legitimacy, we continue the analysis by exploring the perception of the owner-managers on the legitimacy granted by different stakeholders.

\section{Legitimacy, Clients and Collaborators}

To start the analysis, we present the co-occurrences of the codes 'clients' and 'collaborators' with the code 'legitimacy' (see Table 7).

The clients, as part of the dominant stakeholders (Sen and Cowley 2013), are the most important group and client satisfaction is central to any small business. The relationship with clients has to be transparent and respectful and going the extra step is central in building good relationships. The client has to be provided with the best service and the best experience. For example, when asked by an interviewer "If we talk about legitimacy, is the quality of the service provided what makes you legitimate?" "In Lorraine, yes. In fact, in our sector, yes," said one interviewee from the communication sector.

The employees, who are also dominant stakeholders (Sen and Cowley 2013), are likewise considered an important group even though the association between the two codes 'employees' and 'legitimacy' is not as strong as it is for the codes 'clients' and 'legitimacy'. The owner-managers perceive employees as an important source of legitimacy, since they bring the technical competencies which are the basis for providing good quality services. For the owner-managers, employees grant legitimacy if they feel happy and autonomous at the workplace and if they identify with the company. To illustrate this point, one respondent from heavy industry
Table 8 Co-occurrence of codes 'family', 'investors', 'suppliers' and 'community' with code 'legitimacy'

\begin{tabular}{lll}
\hline Code & Frequency & $\begin{array}{l}\text { Co-occurrence with } \\
\text { code 'legitimacy' }\end{array}$ \\
\hline Family & 92 & 3 \\
$\begin{array}{l}\text { Investors (shareholders-18 } \\
\quad \text { and bank-26) }\end{array}$ & 44 & 3 \\
Suppliers & 39 & 2 \\
Community & 13 & 1 \\
\hline
\end{tabular}

stated: "I'm not tough. I let people free, I like autonomy, I like that people feel happy, that they show what they can do but I'm demanding. Because I'm demanding of myself, I'm also demanding of others but this is also a protection of their employment, of the image which we would like to convey." In addition, based on the stakeholder classification by Sen and Cowley (2013), we have included in the analysis the following pertinent codes (see Table 8).

The code 'family' is pertinent when analyzing the legitimacy of SMEs since legitimacy may be derived not only from achieving professional but also personal objectives. According to Sen and Cowley (2013), the family is a discretionary stakeholder, meaning that they have the legitimacy to impose their demands on the SMEs but are lacking power and urgency when compared with the dominant stakeholders. We discovered that for some owner-managers, the personal objectives are related to achieving balance between the professional and personal life. As one interviewee from the accounting sector stated: "I'm also a mother of a family, so I need to find a balance between my professional and my personal life."

The code 'legitimacy' is also associated with the code 'investors', which includes shareholders and banks. The two groups are dominant stakeholders (Sen and Cowley 2013) meaning that they have the legitimacy and the power but do not have the urgency. The relationship is significant in the present study in terms of employees being shareholders and participants in the foundation of the enterprise. The support of the bank, especially in times of crisis, is viewed as a source of legitimacy. As it was stated by one respondent whose enterprise is in heavy industry: "I went to see the bank and I told them that in March, I risk being exposed to an overdraft of 300000 euros. The bank followed us, the customers followed us and finally...we went through, I was able to pay our salaries, I got cash today, so I have 750,000 cash there...to say that we moved from everything to nothing. It's the life of a SME but we made it...this is what made us legitimate."

Another pertinent code, which is related to the code 'legitimacy', is 'suppliers' described in the extant literature as dominant stakeholders (Sen and Cowley 2013). The relationship is not specifically defined, which means 
Table 9 Co-occurrence of codes 'values', 'image', 'responsibility, 'recognition' with code 'legitimacy'

\begin{tabular}{lcc}
\hline Codes & Total frequency & $\begin{array}{l}\text { Co-occurrence with } \\
\text { code 'legitimacy' }\end{array}$ \\
\hline Values & 152 & 12 \\
Image & 50 & 6 \\
Responsibility & 87 & 6 \\
Recognition & 29 & 6 \\
\hline
\end{tabular}

Table 10 Co-occurrence of codes 'certification', 'norms' and 'regulation' with code 'legitimacy'

\begin{tabular}{lll}
\hline Codes & Total frequency & $\begin{array}{l}\text { Co-occurrence } \\
\text { with code 'legiti- } \\
\text { macy' }\end{array}$ \\
\hline Certification & 31 & 3 \\
Norms & 17 & 2 \\
Regulation & 27 & 2 \\
\hline
\end{tabular}

that the interviewees did not particularly talk about the perception that their suppliers have about their enterprise. The same conclusion is reached when it comes to the code 'community'.

To conclude, the owner-managers of SMEs perceive their clients as the primary stakeholder group, whose evaluation on the products and services is of central importance for the legitimacy of their enterprise. The employees, whose competencies are the basis for clients' satisfaction, are also perceived as primary stakeholders. The owner-managers evaluate family, investors and the sector (or peer group of companies) as secondary stakeholders. The importance of each type of stakeholder is different depending on the urgency of the issue (for example, during crisis, receiving a credit from a bank has an important legitimizing role) and the personality of the owner-manager (for example, family is more important for some managers than others). Surprisingly, the owners-managers do not refer to the suppliers and the local community in their discourse.

\section{Legitimacy, SMEs, Challenges}

The co-occurrences between the code 'legitimacy' and the codes 'values', 'image', 'responsibility' and 'recognition' is presented in Table 9.

The analysis of the code 'legitimacy' reveals that small companies face particular challenges when trying to acquire and convey their legitimacy. We regrouped the following co-occurring codes under challenges: values (12), image (6), responsibility (6) and recognition (6) (see Table 8). The non-frequent but pertinent codes added to the analysis are the following: certificates (3), norms (2) and regulation (2) (see Table 10).

In maintaining their legitimacy, SMEs face certain challenges and we acknowledge the importance of internal values and responsibilities of SMEs and their external image and recognition. Therefore, we group the codes 'values' and 'responsibilities' together since our data show that often the values expressed by the owner-manager are associated with the responsibility they have towards their employees (for example, participative management, serenity and harmony in the workplace, training and transfer of knowledge as well as flexibility, adaptability, openness to learn, etc.). Ownermanagers feel responsible to transfer to their employees the values of how to treat (listen and communicate to) the client as well as how to develop team spirit where the success of the team is more important than the personal success of the owner-manager. As one interviewee from the communication sector stated: "Eventually, we don't have this drive for personal success but for the success of the team." In addition, SMEs feel responsible towards other companies in the same sector of activity with which they want to share best practices. In the words of one interviewee from the personal services sector "We don't want to keep this for us, we think we should share things, so that the sector can have good practices." The main challenge that emerges when it comes to conforming to the system of values is the management of conflicting interests of different stakeholders. This makes conforming to the already-established system of values very challenging. As one interviewee whose enterprise is in the communication sector stated: "We're at the intersection of many things, involving customers, requirements, production, norms, what we have to do, the responsibility we have. And then the employees who also have their requirements. So, legitimate or not ...let's say that one can have a value system that is not always easy to manage."

In terms of the codes 'image' and 'recognition', small business managers expect recognition from their primary stakeholders (clients and employees). Hence, they strive to convey an image of exemplarity related to the products and services provided to their clients as well as the leadership to their employees. Moreover, being exemplary for some owner-managers represents the core of their work. The image of exemplarity is extended to the tangible part of the company (shops, trucks, offices), which have to be well-arranged, clean and pleasing to observers. This helps convey the image of excellent quality. In the words of one interviewee whose enterprise is in the communication sector: "So, as I always say a well-arranged van, a tidy shop, clean offices is important, it also gives the image of the service." The way some owner-managers measure their recognition is the degree of respect accorded to them by different stakeholders. The attitude of respect indeed shows recognition of their efforts and a positive image of 
the company. For example, one respondent from the communication sector emphasized the importance of having "respect of people, of all people. Whether it's a worker who comes to work from outside to fix the water tap or people who come to us, a customer, there is always at the core this ... this respect."

Another important group of challenges is represented by the combination of the codes 'certificates', 'norms' and 'regulations'. These codes encapsulate the struggle of SMEs to conform to the requirements of the industry/sector in which they operate. For example, in the personal services sector in France, private enterprises are not illegal but lack cultural-cognitive legitimacy; the taken-for-granted assumption implying that it is the government that provides those services. One interviewee in personal services sector said: "At this level, our legitimacy is often questioned by certain ministers who make us understand that companies do not have anything to do in this domain." Some owner-managers recognize that conforming to the industry norms and to the demands and requirements of different stakeholders is difficult since stakeholders can have conflicting interests. In the words of one respondent whose enterprise is in the accounting services sector: "Well, to satisfy everyone, from the outset, the customer, the employees, who sometimes criticize us for not being attentive enough... is difficult." In addition, they express support for the emergence of industry norms and regulations (in sectors where they are not strictly defined) since they expect that this will reduce the competitive pressures on small businesses.

In some industries/sectors, the norms are embedded in certificates. Even though some owner-managers recognize that the certification is not pertinent for their sector of activity, others state that while they do not have the means to pursue certification, they have implemented internal procedures in order to match the industry norms. In the words of one owner-manager in the consulting sector: "So, we have internal procedures, we do not have certification yet because I think that our size does not justify it at the moment. But we have procedures in place. There are procedures that are largely modeled on the regulatory part, even for the nonregulatory part. So, with a certain number of obligations in order to facilitate the work." Owner-managers who opted for certification expressed what they considered its positive and negative aspects. On one side, procedures of production are well outlined and following them assures high quality of production. On the other side, certificates are associated with lack of flexibility since there are strict procedures in place. The importance of certification in times of crisis is highlighted. When the level of confidence between the different economic actors is very low, having a certificate is viewed as a source of legitimacy. The words of one interviewee from heavy industry were typical of this view: "Today, one new thing that ISO brings to us is legitimacy as an enterprise, because during these six years of crisis and difficulties, people didn't trust each other."

At the same time, in other sectors, the constantly changing regulations pose a problem to SMEs since they have to mobilize their scarce resources in order to respect the requirements of the regulatory authorities. Some ownermanagers criticize the government, which they blame for not taking into consideration the challenges that SMEs face and for frequent regulatory changes. In the words of an interviewee whose company is an industrial enterprise: "That's really a concern for me, rather than having authorities that help us, help us grow, help us create wealth and value, I'm facing authorities that are constantly imposing norms, regulations, precautionary standards that I sometimes consider excessive, other times completely incomprehensible and which are all obstacles to the growth and development of the company and ultimately to its competitiveness. It is also one of the major challenges I am currently facing." In addition, respecting the law is perceived not to be sufficient for the survival of an organization. Companies need to have competencies in order to meet the requirements of the clients.

To conclude, some challenges lie at the interplay between responsibility, values, image and industry norms. This dimension explains the triple challenges that the ownermanagers perceive that their companies face in managing their legitimacy. First, they need to respond to the conflicting interests of the different stakeholders; their values and resources could be at stake. Prioritizing is a challenge, and it depends on the situation and the personality of the ownermanager. Second, managing the image of the enterprise by conveying the perception of exemplarity is a challenge due to limited resources and the much bigger consequences for a small company than a big one when clients/employees' expectations are not met. Third, conforming to the industry norms is difficult for SMEs since they need to channel limited resources in order to get certified, create internal procedures and/or adapt to the ever-changing government regulations.

\section{Discussion}

In this article, we employ legitimacy-as-perception perspective (Suddaby et al. 2017) and examine the bases on which the individual legitimacy judgments (Tost 2011) of SMEs' owner-managers are formed. In particular, we study their judgements of the legitimacy of their own enterprise (propriety) and the perception they hold about the legitimacy judgements coming from different stakeholders (validity beliefs) (Bitektine and Haack 2015). The analysis shows that the SME owner-managers evaluate the legitimacy of their enterprise based on its basic functions in a rather concrete and practical manner by employing instrumental, relational 
Table 11 Type of evaluation used in individual legitimacy judgements by SMEs' ownersmanagers

\begin{tabular}{llll}
\hline \multirow{2}{*}{$\begin{array}{l}\text { Type of } \\
\text { evaluation }\end{array}$} & \multicolumn{1}{c}{ Individual legitimacy judgements of owner-managers of SMEs } \\
\cline { 2 - 4 } Instrumental & $\begin{array}{l}\text { Fegitimacy is granted } \\
\text { enterprise (overcoming } \\
\text { financial difficulty) }\end{array}$ & $\begin{array}{l}\text { Legitimacy is doubted } \\
\text { of the family }\end{array}$ & $\begin{array}{l}\text { Legitimacy cannot } \\
\text { be evaluated }\end{array}$ \\
\hline \multirow{3}{*}{ Relational } & $\begin{array}{l}\text { Respect and } \\
\text { recognition from } \\
\text { external stakeholders } \\
\text { (clients, employees, }\end{array}$ & \\
interns, etc.) & & \\
\hline Moral & $\begin{array}{l}\text { Responsibility towards } \\
\text { clients (customer } \\
\text { experience and } \\
\text { satisfaction) and } \\
\text { employees (leadership) }\end{array}$ & $\begin{array}{l}\text { Inappropriate; against } \\
\text { the value of humility }\end{array}$ \\
\hline
\end{tabular}

and moral evaluations. Instrumental evaluations are associated with material interest of the individual, the relationalwith the respect, dignity and status that an individual gets by being part of a group and moral evaluations-with the set of values guiding the morality of the evaluator (Tost 2011). This supports the finding of Bitektine and Haack (2015), who state that "depending on which set of norms is selected, an evaluator can arrive at different legitimacy judgments about an organization, which leads to diversity of legitimacy judgements at the micro level" (Suddaby et al. 2017). Hence, we found that they can state either that their enterprise has legitimacy (based on instrumental, relational and moral evaluations), does not have legitimacy yet (based on instrumental evaluations) or that they are not in a position to judge their own legitimacy (based on moral evaluations) (see Table 11).

Most managers that state their enterprise has legitimacy are usually confident about the value of the products/services provided by their enterprise, which results in client satisfaction. Often, these managers support their statements by employing three types of evaluations: instrumental (positive financial results), relational evaluations (i.e. respect of clients) and moral evaluations (responsibility to clients by always going the extra step, or responsibility towards employees).

Even if it happens rarely, some managers doubt the legitimacy of their enterprise, according to our findings. These managers employ mainly instrumental judgements in the sense that they expect to ensure certain financial security for their families in order to grant themselves and their enterprises legitimacy. In these cases, it is hard to distinguish between the personal legitimacy of the owner-manager and the legitimacy of his/her enterprise.
When owner-managers state that they are not in a position to judge their company's legitimacy, they usually draw their legitimacy judgements on moral evaluations since they state that such self-acknowledgment is inappropriate and against their values (such as humility).

The results are summarized and presented in Table 11.

In addition, the diversity of legitimacy judgments employed by the owner-managers when they evaluate the legitimacy of their enterprise leads to different types of legitimacy sought by the enterprise-regulatory, normative (technical and/or managerial), cultural-cognitive. For example, the instrumental judgment of the financial profitability of an enterprise as a signal of its legitimacy is related to the cultural-cognitive belief of the purpose of the enterprise-it has to have financial vitality. Hence, when employing instrumental judgments, owner-managers prioritize the culturalcognitive legitimacy. In contrast, when employing relational and moral judgements related to the respect granted by the clients and the employees as well as the responsibility they have towards them, they seek rather technical and managerial legitimacy. It is also interesting to look at the cases when legitimacy is not granted which is based on the financial performance of the enterprise and it goes back to culturalcognitive belief of the purpose of an enterprise. In addition, when owner-managers state that they are not in a position to judge the legitimacy of their own enterprise, they refer to their moral values. Therefore, based on the evaluation employed, we can state that the owner-managers look for different types of legitimacy (see Fig. 1).

In terms of evaluating the legitimacy perceptions of stakeholders, we discovered that they are divided into two stakeholder groups_-primary (clients and employees) and secondary (banks/investors, government, sector, and family). 
Fig. 1 Legitimacy judgments of SME owner-managers (LJSOM)

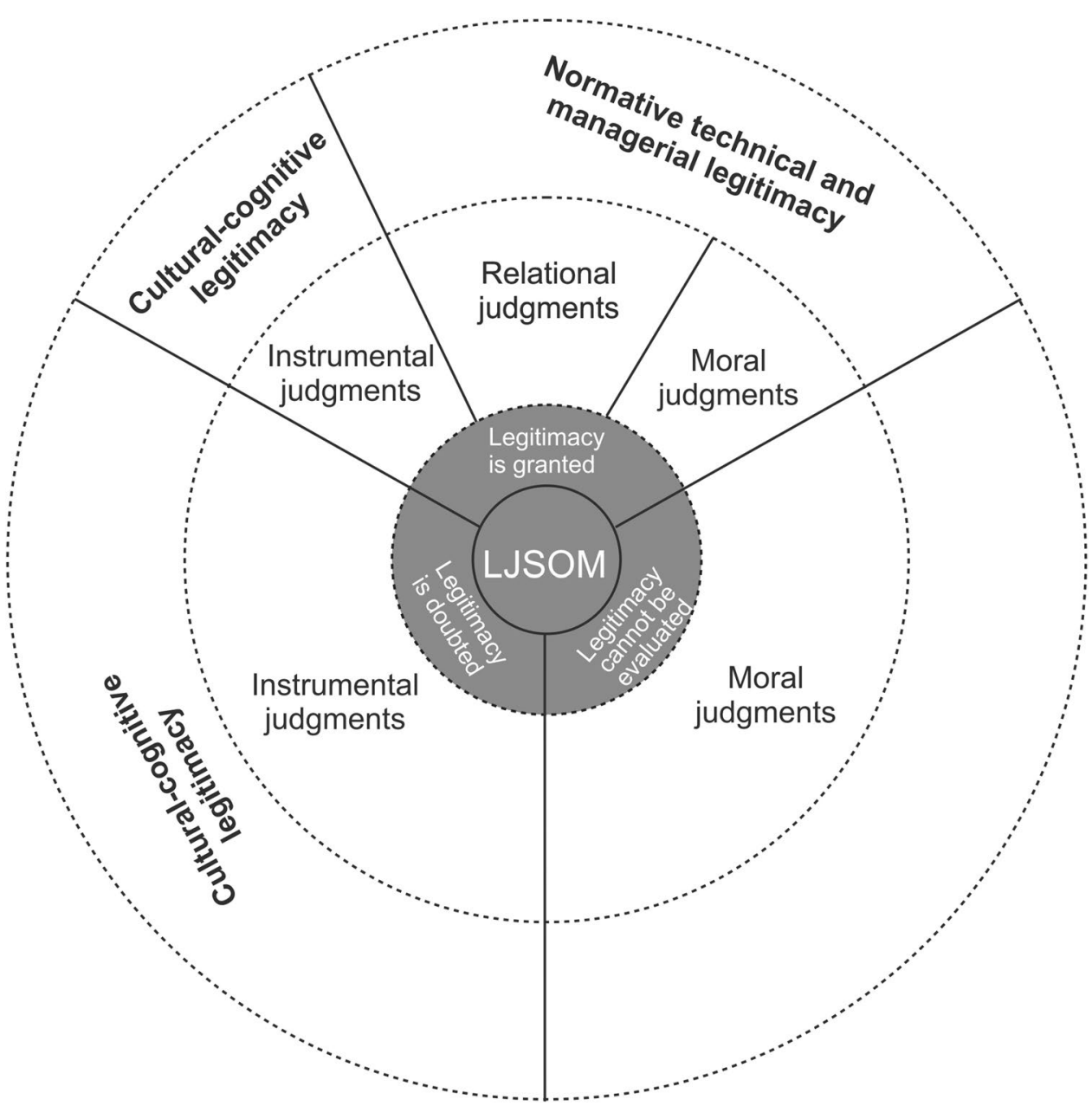

The most important validity cues are considered the ones that come from the clients, and for some owner-managers having clients can be a sufficient signal of legitimacy. Validity cues coming from employees are rated high since they are repositories of technical competencies and providing training and good treatment is of central importance for small business managers. Hence, our research shows that not all dominant stakeholders (Sen and Cowley 2013) are perceived to be of equal importance in the formation of individual legitimacy judgments of small business owner-managers. They put much more emphasis on the validity cues coming from the clients and employees than from investors and suppliers. In fact, validity cues coming from other stakeholders, such as the government, investors, sector and family, which represent a mix of dominant and discretionary stakeholders (Sen and Cowley 2013), have secondary importance. Even though the SMEs' owner-managers recognize the role of conforming to them in order to gain legitimacy, they are not crucial in the formation of their individual legitimacy judgement (see Fig. 2).

It is also important to highlight the challenges that SMEs face while trying to balance between conflicting demands of stakeholders. The moral evaluation of the enterprise based on the personal values of the owner-manager might be in conflict with the validity cues coming from some stakeholders. For example, working long hours in order to provide consistently excellent quality expected from clients, can be in conflict with the personal interests of the employees as well as the family of the owner-manager and his/her own values. Also, not paying oneself a salary when the company is going through a financial difficulty can go against the interest of the family. When conflict exists between the personal feelings of obligation towards external entities (legitimacy) and the moral values of the owner-manager (Tyler 2006), this can introduce confusion for the evaluator. Since the legitimacy of an SME (as it is with any other entity) can be contested at any given point in time, it has to be constantly re-negotiated with the environment-a process called 'legitimacy reassessment' (Tost 2011). 
Fig. 2 Sources of legitimacy judgments for SME ownermanagers $(\mathrm{SOM})$

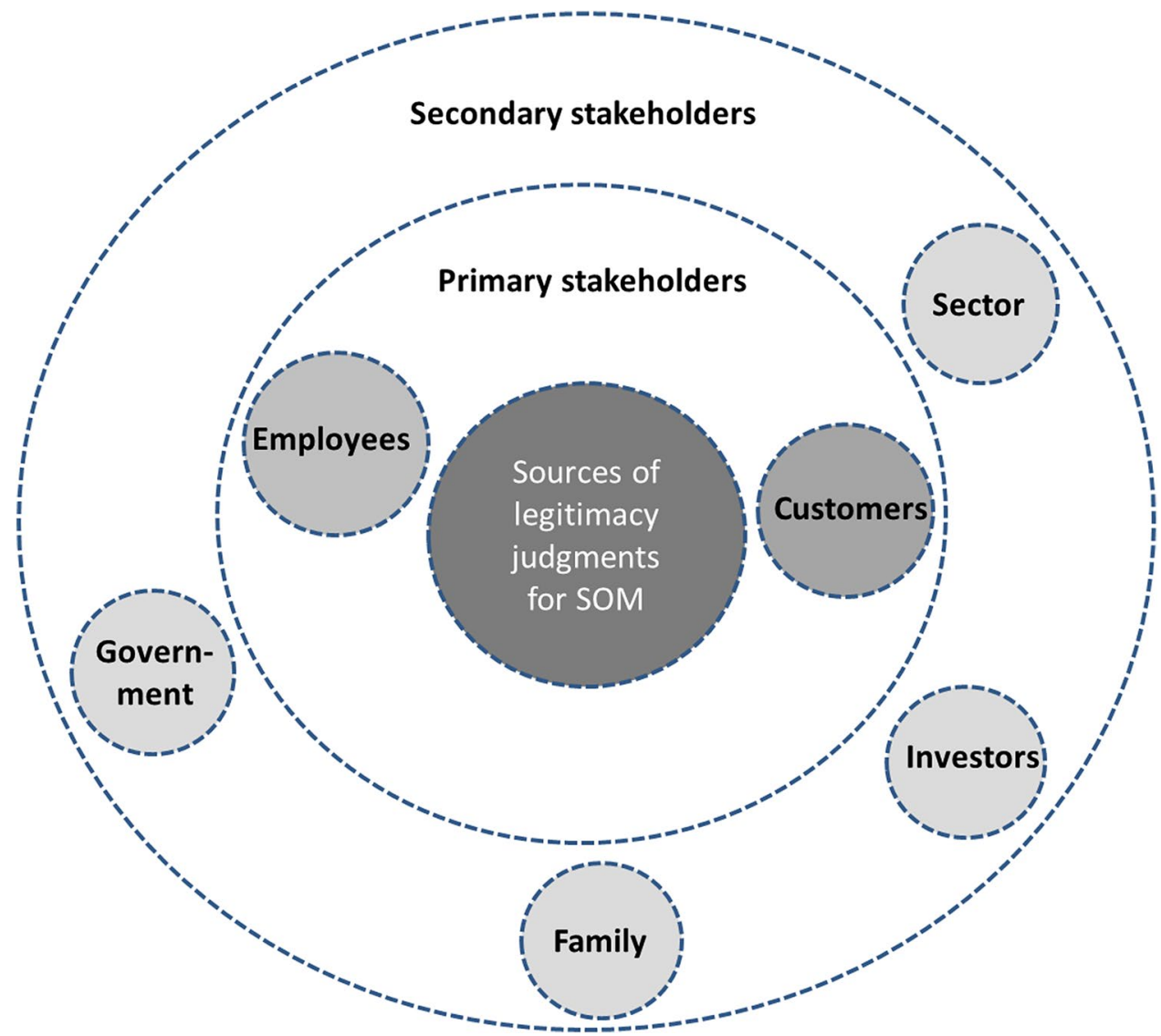

\section{Contributions and Avenues for Future Research}

Since legitimacy is a social construct, legitimacy judgments of individuals are rarely studied in the literature (Tost 2011). Hence, this article sheds some light on the interplay between the individual and collective level of legitimacy formation (Bitektine and Haack 2015) by examining how owner-managers of SMEs judge the legitimacy of their own enterprise as well as the perception of the SME's legitimacy held by relevant stakeholders. We focus on the individual legitimacy judgement by directly asking owner-managers whether they perceive their enterprise legitimate and why. The individual legitimacy judgements of small business managers are of fundamental importance for the SMEs' behavior and survival since they are directly linked to the feelings of responsibility and obligation held by the owner-managers towards their own enterprise and relevant stakeholders.

Our findings show that owner-managers base their evaluations on instrumental, relational and moral cues when they perceive that the enterprise has legitimacy, on instrumental cues when they perceive the enterprise does not have legitimacy and on moral cues when they state that they are not in position to evaluate the legitimacy of their enterprise. Future studies can examine why and under which conditions owner-managers employ instrumental, relational and moral cues. For example, Tyler (2006) reported that relational concerns dominate individual legitimacy judgements in cases of conflict between supervisors and subordinates. In addition, our research shows that when SME owner-managers adopt instrumental judgements, they refer to cultural-cognitive legitimacy or more importantly to the cultural-cognitive belief about the purpose of an enterprise. When they employ relational and moral judgement, they refer to normative legitimacy (technical and managerial). Technical legitimacy is associated with client satisfaction based on the quality of the products and/or services provided. Managerial legitimacy is associated with employees' respect and satisfaction with the management of the company as well as the working conditions. Respecting the sector's rules and regulations (or regulatory legitimacy) is not perceived as a sufficient basis of legitimacy of their enterprise.

In addition, our article breaks down the validity cues based on the different stakeholder groups. Not surprisingly, the owner-managers judge the cues coming from their clients as being the most important followed by the ones coming from their employees. This shows that not all dominant stakeholders (Sen and Cowley 2013) have the same importance for small business managers; some of them (clients and employees) tend to be ranked higher in the process of 
legitimacy judgement-formation. Moreover, the interviews reveal that SME owner-managers do not consider suppliers, banks/investors and communities as decisive stakeholders. This is a surprise since suppliers and banks/investors are considered dominant stakeholders (Sen and Cowley 2013). Banks and investors seem to be important when the issue has a certain level of urgency or in other words, they can change from being of secondary importance to being very important if the company requires financing. This finding supports previous research (Mitchell et al. 1997; Sonpar et al. 2010) which emphasized the dynamic nature of stakeholder salience. Being embedded in their communities and exposed to higher institutional pressures (Russo and Perrini 2010) makes validity cues coming from communities important for SMEs. However, our data does not show that owner-managers are concerned with validity cues coming from them. Future research can further explore this issue.

In addition, our research shows that there are situations when the individual legitimacy judgments and the moral values of an owner-manager might be in conflict. They are both internal values which determine the individuals' feelings of obligation and behavior (Tyler 2006). In most of the cases, they are aligned but sometimes, they can be in conflict, such as when the owner-managers face the obligation to complete work for a client and their moral value of treating the employees correctly are at stake. It will be intriguing to study what type of legitimacy judgments dominates the perception of managers in cases of conflict. And also how these conflicts are resolved.

This research presents some limitations. Even if it is not the scope of this study, it would have been noteworthy to analyze stakeholders' perception of each SME's legitimacy and match it with managers' perception. Our study considers only the individual legitimacy judgment of the SMEs' owner-managers. And the validity cues as interpreted by them are not analyzed in the light of direct stakeholders' perception. Future studies can actually collect data on the legitimacy perception of different stakeholders. Second, our sample is comprised of enterprises, which come from the region of Lorraine in France. We did not acknowledge the role of culture but this is an important aspect when we evaluate individual legitimacy judgements. For example, as we saw here, many SME owner-managers in France use instrumental, relational and moral evaluations when they state that their enterprise is legitimate, which may not be the case in other countries. Third, the research does not look at the way the validity cues influence the propriety of owner-managers regarding their own legitimacy (Suddaby et al. 2017) even though one of our findings is that the validity cues coming from the customers are considered to be the most important ones. Forth, legitimacy is not studied in terms of its degrees or levels (Brummer 1991) since the owner-managers were simply asked whether their enterprise is perceived to be legitimate and why. The researchers recognize that it is probable that the owner-managers refer to different degrees of legitimacy, but this was not acknowledged in our study.

Exploring the process of individual legitimacy judgment formation requires more attention from the researchers (Tost 2011). The legitimacy of small enterprises is an important issue that could explain their behavior. Future studies can explore the link between individual legitimacy judgments and the behavior of small businesses. Along these lines, it would be interesting to examine whether the legitimation strategies used by the owner-managers do not differ based on the formers' individual legitimacy judgments and also based on their sector of activity.

\section{Compliance with Ethical Standards}

Conflict of interest All authors declare that they have no conflict of interest.

Ethical Approval All procedures performed in studies involving human participants were in accordance with the ethical standards of the institutional and/or national research committee and with the 1964 Helsinki declaration and its later amendments or comparable ethical standards.

Informed Consent Informed consent was obtained from all individual participants included in the study.

\section{References}

Berger, P. L. (1981). New attack on the legitimacy of business. Harvard Business Review, 59(5), 82-89.

Bitektine, A. (2011). Toward a theory of social judgements of organizations: The case of legitimacy, reputation, and status. Academy of Management Review, 36(1), 151-179.

Bitektine, A., \& Haack, P. (2015). The "macro" and the "micro" of legitimacy: Toward a multilevel theory of the legitimacy process. Academy of Management Review, 40(1), 49-75.

Boiral, O. (2003). ISO 9000: Outside the iron cage. Organization Science, 14(6), 720-737.

Bruderl, J., \& Schussler, R. (1990). Organizational mortality: The liabilities of newness and adolescence. Administrative Science Ouarterly, 35(3), 530-547.

Brummer, J. J. (1991). Corporate responsibility and legitimacy: An interdisciplinary approach. New York: Greenwood Press.

CEDEF (Centre de Documentation Economie - Finance). Où trouver les chiffres clés de PME ? Retrieved May 22, 2018 from https:// www.economie.gouv.fr/cedef/chiffres-cles-des-pme.

Chan, A. C.-S. (2012). Breaking into the international jewelry market: Legitimacy strategies and entrepreneurship of Hong Kong small businesses. International Journal of China Marketing, 2(2), 89-106.

Conseil Economique Social et Environnemental de Lorraine (CESEL). Les indicateurs territoriaux du développement durable de la Lorraine, Février 2013, p. 9.

Cooper, D. R., \& Schindler, P. S. (2001). Business research method (7th edn.). New York: McGraw-Hill Book Co.

Deephouse, D. L. (1996). Does isomorphism legitimate? Academy of Management Journal, 39, 1024-1039. 
Deephouse, D. L., Bundy, J., Tost, L. P., \& Suchman, M. C. (2016). Organizational legitimacy: Six key questions. In R. Greenwood, C. Oliver, T. Lawrence \& R. Meyer (Eds.), The SAGE handbook of organizational institutionalism. Thousand Oaks: Sage.

Deephouse, D. L., \& Carter, S. M. (2005). An examination of differences between organizational legitimacy and organizational reputation. Journal of Management Studies, 42(2), 329-360.

Delmar, F., \& Shane, S. (2004). Legitimating first: Organizing activities and the survival of new ventures. Journal of Business Venturing, 19(3), 385-410.

Dowling, J., \& Pfeffer, J. (1975). Organizational legitimacy: Social values and organizational behavior. The Pacific Sociological Review, 18(1), 122-136.

European Commission. Growth, industry, internal market, entrepreneurship and SMEs. Retrieved June 22, 2017 from https://ec.europ a.eu/growth/smes_en.

Fassin, Y., Van Rossem, A., \& Buelens, M. (2011). Small-business owner-managers' perceptions of business ethics and CSR-related concepts. Journal of Business Ethics, 98, 425-453.

Fitjar, R. D. (2011). Little big firms? Corporate social responsibility in small businesses that do not compete against the Big Ones. Business Ethics: A European Review, 20(1), 30-44.

Freeman, J., Carroll, G. R., \& Hannan, M. T. (1983). The liability of newness: Age dependence in organizational death rates. American Sociological Review, 48(5), 692-710.

Freeman, R. E. (1984). Strategic management: A stakeholder approach. Marshfield: Pitman Publishing.

Fuller, T., \& Tian, Y. (2006). Social and symbolic capital and responsible entrepreneurship: An empirical investigation of SMEs narratives. Journal of Business Ethics, 67, 287-304.

Higgins, M. C., \& Gulati, R. (2006). Stacking the deck: The effects of top management backgrounds on investor decisions. Strategic Management Journal, 27, 1-25.

Hoefer, R. L., \& Green, Jr. S. E. (2016). A rhetorical model of institutional decision making: The role of rhetoric in the formation and change of legitimacy judgments. Academy of Management Review, 41(1), 130-150.

Ivanova, O., \& Castellano, S. (2012). Signaling legitimacy for SMEs in transition environments: The case of the Bulgarian IT sector. Journal of Eastern European Management Studies, 17(4), 398-422.

Jamali, D., Zanhour, M., \& Keshishian, T. (2009). Peculiar strengths and relational attributes of SMEs in the context of CSR. Journal of Business Ethics, 87, 355-377. https://doi.org/10.1007/s1055 1-008-9925-7.

Jenkins, H. (2006). Small business champions for corporate social responsibility. Journal of Business Ethics, 67, 241-256. https:// doi.org/10.1007/s10551-006-9182-6.

Johnson, C., Dowd, T. J., \& Ridgeway, C. L. (2006). Legitimacy as social process. Annual Review of Sociology, 32, 53-78.

Krippendorff, C. K. (2004). Content analysis: An introduction to its methodology. Thousand Oaks: Sage Publications, Inc.

Lepoutre, J., \& Heene, A. (2006). Investigating the impact of firm size on small business social responsibility: A critical review. Journal of Business Ethics, 67(3), 257-273.

McIntyre, R. J. (2003). Small enterprises in transition economies: Causal puzzles and policy-relevant research. In R. J. McIntyre \& B. Dallago (Eds.), Small and medium enterprises in transitional economies. Basingstoke: Palgrave Macmillan.

Meyer, J. W., \& Rowan, B. (1977). Institutionalized organizations: Formal structure as myth and ceremony. American Journal of Sociology, 83, 340-363.

Mitchell, R. K., Agle, B. R., \& Wood, D. J. (1997). Toward a theory of stakeholder identification and salience: Defining the principle of who or what really counts. Academy of Management Review, 22(4), 853-886.

Morin-Estèves, C., Mnisri, K., Ivanova, O., \& Gendron, C. (2017/2018). Les valeurs du dirigeant de PME au service du développement durable: Le cas des PME de la région Lorraine. Management and Avenir, 8(98), 39-61.

Mort, G. S., Weerawardena, J., \& Liesch, P. (2012). Advancing entrepreneurial marketing: Evidence from born global firms. European Journal of Marketing, 46(3/4), 542-561.

Neuendorf, K. A. (2017). The content analysis guidebook. Thousand Oaks: Sage Publications, Inc.

Paradas, A. (2007). Mutualiser la formation et le recrutement dans les PME: Une variété de réponses. La Revue de Sciences de Gestion, 226-227, 147-155.

Peng, M. W. (2003). Institutional transitions and strategic choices. Academy of Management Review, 28(2), 275-296.

Pfeffer, J., \& Salancik, G. (2003/1978). The external control of organizations: A resource dependence perspective (2nd edn.). Stanford: Stanford University Press.

Ruef, M., \& Scott, R. W. (1998). A multidimensional model of organizational legitimacy: Hospital survival in changing institutional environments. Administrative Science Quarterly, 43(4), 877-904.

Russo, A., \& Perrini, F. (2010). Investigating stakeholder theory and social capital: CSR in large firms and SMEs. Journal of Business Ethics, 91, 207-221. https://doi.org/10.1007/s10551-009-0079-z.

Russo, A., \& Tencati, A. (2009). Formal vs. informal CSR strategies: Evidence from Italian micro, small, medium-sized and large firms. Journal of Business Ethics, 85(2), 339-353.

Scott, R. W. (2003). Organizations: Rational, natural and open systems (5th edn.). New Jersey: Prentice Hall.

Scott, W. R. (2001). Institutions and Organizations (2nd edn.). Thousand Oaks: Sage.

Sen, S., \& Cowley, J. (2013). The relevance of stakeholder theory and social capital theory in the context of CSR in SMEs: An Australian perspective. Journal of Business Ethics, 118, 413-427. https ://doi.org/10.1007/s10551-012-1598-6.

Singh, J. V., Tucker, D. J., \& House, R. J. (1986). Organizational legitimacy and the liability of newness. Administrative Science Quarterly, 31(2), 171-193.

Smallbone, D., Piasecki, B., Venesaar, U., Todorov, K., \& Labrianidis, L. (1999). Internationalisation and SME development in transition economies: An international comparison. Journal of Small Business and Enterprise Development, 5(4), 363-375.

Sonpar, K., Pazzaglia, F., \& Kornijenko, J. (2010). The paradox and constraints of legitimacy. Journal of Business Ethics, 95, 1-21.

Soriano, D. R., \& Dobon, S. R. (2009). Linking globalization of entrepreneurship in small organizations. Small Business Economics, 32, 233-239.

Suddaby, R., Bitektine, A., \& Haack, P. (2017). Legitimacy. Academy of Management Annals, 11, 451-478.

Tilley, F. (2000). Small firm environmental ethics: How deep do they go? Business Ethics: A European Review, 9(1), 31-41.

Tost, L. P. (2011). An integrative model of legitimacy judgements. Academy of Management Review, 36(4), 686-710.

Tyler, T. R. (2006). Psychological perspectives on legitimacy and legitimation. Annual Review of Psychology, 57, 375-400.

Westrenius, A., \& Barnes, L. (2013). Managing complex business relationships: Small business and stakeholder salience. The Journal of Developing Areas, 49(6), 481-488.

Zelditch, M. (2001). Processes of legitimation: Recent developments and new directions. Social Psychology Quarterly, 64(1), 4-17.

Zimmerman, M. A., \& Zeitz, G. J. (2002). Beyond survival: Achieving new venture growth by building legitimacy. Academy of Management Review, 27(3), 414-443. 